\title{
Needs Analysis on Training Management Model Development
}

\author{
Fibie Liona Pangaribuan \\ School of Postgraduate, Educational \\ Administration Department \\ Universitas Negeri Medan \\ Medan, Indonesia \\ fibieliona@gmail.com
}

\author{
Darwin \\ School of Postgraduate, Educational \\ Administration Department \\ Universitas Negeri Medan \\ Medan, Indonesia
}

\author{
Wanapri Pangaribuan \\ School of Postgraduate, Educational \\ Administration Department \\ Universitas Negeri Medan \\ Medan, Indonesia
}

\begin{abstract}
Needs analysis is the formal process to determine the gap between the ideal form and the current condition. This research aimed to analyze the needs of developing student training management models in Diploma III mechanical engineering department. This research uses descriptive qualitative approach method. The data is collected by interview, observation and documentation. The subjects of this research are lecturers, instructors, students and the stakeholders. The results shows that: 1) training courses at Diploma mechanical engineering is using guided inquiry models, the training schedule has been set, the competence of the students is already fits to mechanical engineering vision and mission, 2) graduates are currently working in factories based on their Department during college term, and 3) priority needs in the development of training model of management was started from the organization level, i.e by developing a Standard Operating Procedure (SOP) that is in accordance with the vision and mission of mechanical engineering. The implications of this research are: establishment of cooperation with the industry, the improvement of SOP in accordance with the competence needed, and also the improvement of students competence.
\end{abstract}

Keywords- needs analysis, training management model

\section{INTRODUCTION}

Human resources plays a big role hand in promoting the development of a nation. Development in the various sectors of human resources required to compete in national and international scale. The increase in employment without an increase in labor productivity can result in the impoverishment of the labor force due to stagnant wage [1]. Today began the awareness about the importance of human resource management to improve corporate performance, but still have to face many difficulties in the implementation of management and human resource development. There are some things that are the cause of the difficulty. First, the average education level of workers of the construction sector than many other sectors. Secondly, there is the fixed amount of labor used for the manpower needs changing. Third, the reasons subjectively and objectively that limit the participation of workers. [2]. Vocational education and vocational education is a kind of education that specifically prepares students to enter the workforce after completing their studies by providing specific expertise. However, the research results showed that there are number of Unemployment Rate (TPT) is high for graduates of vocational and vocational education as stated in the figure below [3]:

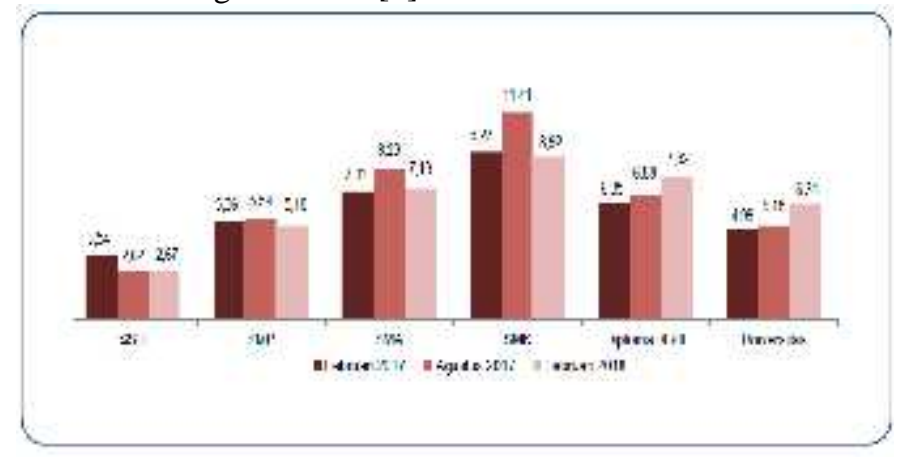

Fig 1. Unemployment Rate in 2017 - 2018

In accordance with Law of Higher Education Article no. 16 Year 2012, the vocational education is education that prepares students to become professionals with skills / high workability [4]. Vocational education curriculum prepared jointly with the professional community and professional organizations are responsible for the quality of service in order to qualify profession professional competence.

There is amount up to $80 \%$ of educational quality problems caused by the management [5]. In order to improve the quality of vocational education, one of the solution is to provide training.

Training planned to be managed in an organized, ranging from planning, organizing and controlling. The four functions of management affects the success of the organization in realizing the vision that has been formulated, even the failure of one of the management functions will result in failure to achieve the vision [6]. Some performance issues with members of organizations that require training are: (1) lack of ability of members, (2) lack of knowledge of members, (3) lack of motivation, (3) behavioral problems [7]. 


\section{LITERATURE REVIEW}

\section{A. Training Management}

Training is primarily an attempt to equip a person with the knowledge and skills and attitude so that a person has the ability to carry out everyday tasks or organizational activity.

Training is an activity to improve the performance of current and future performance [8]. The benefits of training as are: to improve the independence, to increase the motivation, to generate a sense, to increase job satisfaction, and to improve corporate profits [9].

Regarding quality is an issue that has grown and received special attention in higher education, that is focus on quality in higher education triggered by a factor of the number of competitors, political oversight to higher education, as well as the growth and changes to the expected number of students [10]. There are dimensions of quality, namely: access to service, acceptance, efficiency, effectiveness, relevance to the needs, as well as equity [11].

\section{B. Training Needs Analysis}

Needs analysis is defined as a formal process to determine the distance or the gap between the output and the real impact the output and the desired impact, then placing a row this gap in the priority scale, and then choose what is more important to resolve the problem [12].

Training needs analysis is a systematic analysis that determines whether an employee / employees need training or not. Training needs arise if there is a gap between the standards of performance with the work achieves. The process of training needs analysis is very important because it can provide information to organizations about the kind of training and development is needed by workers to improve the effectiveness and efficiency of the organization [13]. The process of training need analysis can be analyzed in several aspects, namely: organizational analysis, task analysis and individual analysis [14].

The purpose of the needs analysis are:

1. Identify a special job performance skills needed to improve performance and productivity.

2. Analyze the characteristics of the participants to ensure that the program is suitable for the level of education, experience and skills as well as attitudes and motivation of a person.

3. Develop specialized knowledge that can be measured and objectively. In this stage there should be a belief that the decline in performance can be improved through training and not due to dissatisfaction with the compensation. [15]

\section{METHOD}

This study is a descriptive study with qualitative approach. Qualitative descriptive research type used in this research is intended to obtain in-depth information about the actual condition of management training, as well as factors that affect training and relation to the profile of graduates and student learning outcomes Mechanical Engineering Diploma III studentss Mechanical Engineering Universitas Negeri Medan.

Sampling or other sources of data in this study is purposive sampling and for the sample size determined snowball, data collection techniques with triangulation (combined), are qualitative data analysis and research results emphasize the significance of generalization.

This study will be conducted at the State University of Medan. This study was conducted over three months, i.e starting from the month of May 2019 until the month of August 2019.

The research procedure is as follows:

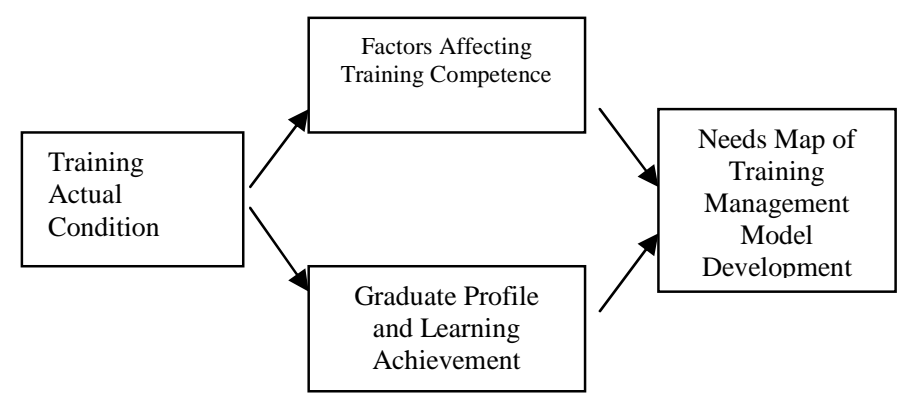

Fig 2. Research Approach

\section{RESULT AND DISCUSSION}

Vocational education is an education program that is designed to produce graduates who have expertise in a particular field. In accordance with the National Qualifications Framework Curriculum Indonesia (KKNI), Diploma 3 belonging to the qualification level 5 , where the graduate is deemed capable of completing the job berlingkup spacious by choosing a variety of methods. Training is one way to improve students' skills in mastering certain skills. In the study program Mechanical Engineering Diploma 3 Unimed, students need to be trained in designing production machines, to be able to master the competencies needed to compete in the industrialized world.

The objective of management training needs analysis are:

1. To see the actual student competence in accordance with the applicable SKKNI

2. To menyesuaian existing training with industry needs

3. Preparing students to become professionals who are able to compete in the world of work

The approach used in analyzing the needs of management training in Mechanical Engineering Study Program D3 Unimed is to look at three components of a needs analysis, ie organizational analysis, task analysis and individual analysis. Then the third aspect of the quality seen by Tovey quality theory, namely the quality of service access, acceptance, efficiency, effectiveness, relevance to the needs and equality. The training in Prodi D3 Mechanical Engineering Unimed accordance with the schedule set by the University, which is 16 times face to face. The training model used is guided inquiry. Is guided inquiry learning process with the guidance 
and direction of the instructor / trainer on an ongoing basis in accordance with the clock face in the classroom and in the practice room.

Training management model currently implemented in Mechanical Engineering Study Program Diploma 3 Unimed is guided inquiry, where students work collaboratively, guided by faculty as an instructor in guiding, correct deficiencies and improve student understanding.

\section{Actual Condition of Competence Development}

\section{A. Organizational Analysis}

The training is done to improve the competence of students, especially in psychomotor. Facilities and infrastructure are used in the training Workshop / Workshop on Mechanical Engineering, with various lab in it among others: CNC Lab, Lab Machines, and so on. Lab Practical activities carried out in accordance with his courses. Basic machining tools are supplied complete, but still need a variety of machine tools that fit the needs of the industry.

\section{B. Task Analysis}

Each lecturer/instructor has job description, respectively, as set forth in Semester Lesson Plan. Each lecturer will get an assessment questionnaire distributed to student assessment, including an assessment based on student competency during the training process.

The training modules owned by the instructor is still very limited in number, there is even less likely. Lecturers that administer refer to RPS, thus making the module or manual have not been realized.

\section{Individual Analysis}

The analysis focuses on the individual itself. This analysis deals with people who are in organizations that require training and development in a particular field. Individual work performance or results may be based on data and assessment of performance compared to the expected level of performance standards specified or organization.

Total students D3 Mechanical Engineering Unimed an average of 15-20 students per year. It is adapted to the capacity of the classroom, as well as facilities and infrastructure practice.

\section{Graduate Profile and Learning Achievement}

The alumnus of Mechanical Engineering Department are currently working in the industrial factories, such as: PT. RAPP Pekanbaru, Indonesia Power, PLTU Surabaya, PT. Mabar Electronics, etc. It implies that the alumnus have worked as expected by mechanical engineering department, that is to work in industrial factories as technician, laboratory assistant, and entrepreneur.

The students of mechanical engineering department have joined many competitions, such as Students Creativity Program - Technology (PKM-T). In this competition, the students make several machine products which ease the process of producing something, such as palm oil harvesting, garbage cleaner, etc. It shows that the students already have the competence in designing and producing machines.
However, there are several weakness in designing the products, such as: lack of designing the appropriate technology for the community. This shortcoming happens due to the lack of lecturer guidance in finding the right technology of the students.

\section{Needs Map}

The researchers have found the quality of several aspects in training management, which listed as follows:

TABLE I. PERCENTAGE OF TRAINING QUALITY

\begin{tabular}{|c|c|c|c|}
\hline No & Quality & Aspect & Percentage (\%) \\
\hline \multirow[t]{3}{*}{1} & \multirow{3}{*}{ Access to Service } & Organizational & 90 \\
\hline & & Task & 75 \\
\hline & & Individual & 93.75 \\
\hline \multirow[t]{3}{*}{2} & \multirow[t]{3}{*}{ Acceptability } & Organizational & 58.5 \\
\hline & & Task & 70 \\
\hline & & Individual & 75 \\
\hline \multirow[t]{3}{*}{3} & \multirow[t]{3}{*}{ Efficiency } & Organizational & 79.16 \\
\hline & & Task & 87.5 \\
\hline & & Individual & 83.3 \\
\hline \multirow[t]{3}{*}{4} & \multirow[t]{3}{*}{ Effectiveness } & Organizational & 75 \\
\hline & & Task & 91.67 \\
\hline & & Individual & 62.5 \\
\hline \multirow[t]{3}{*}{5} & \multirow[t]{3}{*}{ Relevance to Needs } & Organizational & 62.5 \\
\hline & & Task & 75 \\
\hline & & Individual & 75 \\
\hline \multirow[t]{3}{*}{6} & \multirow[t]{3}{*}{ Equity } & Organizational & 68.75 \\
\hline & & Task & 75 \\
\hline & & Individual & 87.5 \\
\hline
\end{tabular}

Based on table analysis obtained by researchers, it is found thatpriority needs of Diploma III Mechanical Engineering in the development of training management model are:

\section{Training model development}

Training management model currently in force in Prodi D3 Mechanical Engineering Unimed is guided inquiry, the student gets assistance from the lecturer (instructor) during the training process. The problem appears when the students cannot find the appropriate solution to overcome the problems in the society. The students are lack of literature reviews so that they couldn't specify the needs of the society. Moreover, the mechanical engineering department should have a training model which differs from the theory teaching model, since the training model has a lot of practices. Furthermore, the needs of integrated module is needed to guide the students in designing the machinery product.

One of obstacle in the training process is the lack of a Standard Operating Procedure (SOP) in ongoing training. Implementation of SOP training depends only on the existing courses, with the consideration that the training undertaken together with the subjects. The need for specific SOP will assist instructors during training indoors. SOP can be done by looking at the training management training models that already exists. 


\section{Competence Test Centre}

The students' competence is currently marked by the work evaluation. The evaluation sheet does not have proper criterion, which compound the instructor to define students as competent enough or not.

This is because there is no place Competency Test in Mechanical Engineering Department. Diploma III Mechanical Engineering Department should require Competency Test place as a tool to test their competency and give the certificate as reward, which can be used in applying for work after they graduate.

\section{Improved infrastructure}

Currently, Diploma III Mechanical Engineering Unimed focused in designing machine-based production with heavy equipment, such as iron, steel and aluminum. Machinery designer in Prodi D3 Mechanical Engineering Unimed also leads to the manufacture of basic materials of iron, steel and aluminum, while many industrialized world that does not use it anymore. The mechanical engineering department needs to pay attention to the needs of infrastructure for light-based tools, such as polymers, etc. The aim is that the process of learning and training undertaken by students is suitable with the industrial world.

\section{CONCLUSION}

Analysis of development needs in the training management model Prodi D3 Mechanical Engineering Unimed based on organizational analysis, task analysis and the analysis of the individual, as well as looking at the quality of these three aspects using Tovey quality theory. Where the study was to answer the research objectives, namely:

1. The actual condition of the implementation of the increase in student competence Diploma Mechanical Engineering Unimed namely:

1) The training is done with a model of guided inquiry such as mentoring by faculty as an instructor for one semester

2) The training activities together with existing courses as a form of practice of the theory taught in the lecture

3) Workshop has had a fairly complete Laboratory, such as Smart Lab and CNC Lab. The machining tools are used to concentrate the iron, steel and aluminum.

2. Profile graduate students Diploma Mechanical Engineering Unimed has been in line with expectations, but for the amount still can not be detected with perfect because it has no management tracer. Students have had the expected competencies in learning outcomes, which can be seen from the student's participation in various the expected competencies in learning outcomes, which can be seen from the student's participation in various competitions. But in learning, there are difficulties in meeting the prerequisites specific skills, such as designing appropriate production machines.

3. can be seen from the student's participation in various the expected competencies in learning outcomes, which can be seen from the student's participation in various competitions. But in learning, there are difficulties in meeting the prerequisites specific skills, such as designing appropriate production machines.

4. Map design development needs training to improve competency management model student Diploma Mechanical Engineering Unimed priority to:

1) Competency Test Centre

2) Improved infrastructure

3) Management training is focused on SOP in accordance with the models of existing training.

\section{REFERENCES}

[1] International Labour Organization, 2017. Laporan Ketenagakerjaan Indonesia: Memanfaatkan Teknologi untuk Pertumbuhan dan Penciptaan Lapangan Kerja. Jakarta: ILO

[2] R. Herison. 2017. Faktor Sumber Daya Manusia yang Meningkatkan Kinerja Pegawai di Yayasan-yayasan Bajiminasa. Jurnal Capacity, Vol. 12(1), pp. 770-775

[3] Badan Pusat Statistik. 2018. Keadaan Ketenagakerjaan Indonesia Agustus 2018.

[4] Law of Higher Education Article no. 16 Year 2012

[5] H. Usman. 2008. Manajemen Teori: Praktek dan Riset Pendidikan. Jakarta: Bumi Aksara

[6] W. Pangaribuan. 2017. Pengaruh Budaya Organisasi, Komitmen Organisasi, Komunikasi Interpersonal dan Efektivitas Sistem Pengendalian Manajemen Kinerja terhadap Kinerja Dosen. Doctoral Thesis. Medan: Unimed.

[7] D. Leigh. 2006. The Group Trainers Handbook: Designing And Delivering Training For Groups. London: Kogan Page

[8] V. Rivai. 2010. Manajemen Sumber Daya Manusia untuk Perusahaan. Jakarta: Grafindo.

[9] Suparyadi. 2015. Manajemen Sumber Daya. Manusia. Yogyakarta: Penerbit Andi

[10] C. Nair., et al. 2010. Leadership and Management of Quality in Higher Education. United Kigdom: Chandos Publishing.

[11] Tovey, Phillip. 1994. Quality Assurance in Continuing Professional Education, An Analysis. New York: Routledge.

[12] R. Kaufman., W.F. English. 1979. Need Assesments Concept and Aplication. New Jersey: Educational Technology Publications.

[13] D. Hanggraeni. 2012. Manajemen Sumber Daya Manusia. Jakarta: Lembaga Penerbit Fakultas Ekonomi Universitas Indonesia

[14] W. Mondy., J. Martocchio. 2016. Human Resource Management. USA: Pearson Education Limited.

[15] S. Panggabean., Mutiara. 2004. Manajemen Sumber Daya Manusia Bogor: Ghalia Indonesia 